\title{
Assessment of Tax Collection System and Its Challenges on Category ' $C$ ' Tax Payers (The Case of Nekemte Town)
}

\author{
Dandi Boru \\ University College, Oromia, Nekemte Campus, Office of Research and Publication
}

\begin{abstract}
The study was designed to assess tax collection system and its challenges on category ' $\mathrm{C}$ ' tax payers in Nekemte town. The problems identified were the tax collection problems related to tax office and tax payers. The data was collected from 15 tax office employees and 70 tax payers using questionnaires and analyzed using the descriptive tools. The finding shows that The study indicated that lack of awareness creation programs for taxpayers, failure of most of the taxpayers to maintain books of account to control their operations, lack of adequately qualified personnel, lack of objective tax estimation procedures and the resultant tax under- and over-statement, lack of taxpayers awareness about tax procedures and calculations are some of the major problems on category "C" tax assessment and collection of we believe this problems will be simplified if not eliminated. The study recommended that the tax office has to deploy reasonably adequate personnel both in terms of number and experience. Furthermore, the provision of appropriate training to these personnel has to be reinforced. Functions such as tax assessment, collection, awareness creation, providing information, and enforcement has to performed effectively and efficiently, so that the tax office would stand strong and powerful.
\end{abstract}

Keywords: Tax, Taxation collection system, Tax assessment, Challenges, Tax payers, Tax collectors, Category C

DOI: $10.7176 / \mathrm{RJFA} / 10-15-01$

Publication date: August $31^{\text {st }} 2019$

\section{Introduction}

According to Lee and Richard (1998), in different tax regimes of many countries, taxes are levied on different sources of income classified in to some number of segments. Largely, countries set their source of income tax taxpayers in to small, medium, and large taxpayers mainly depending on the amount of income derived by the taxpayers. Tax law frameworks of different countries including Ethiopia provide specific rules governing the assessment method, tax rate, accounting period, deduction, exemption, and other related guidelines for each of the above listed group of taxpayers. Although the impacts of application of different types of income tax assessment mechanisms would also deserve discussion, the theme of this article is on the 'efficiency 'of the standard assessment as implemented for assessing income tax liability of the small businesses, contextualized as 'Category C Taxpayers' (taxpayers whose annual income turnover is less than or equal to 100,000 Birr) in Ethiopia (Income tax Proc. no. 286/2002). During the initiation of the Income Tax Proclamation No.286/2002, there have been many expectations to be optimistic in one hand and concerning issues on the other hand about the efficiency of the provision of standard assessment to assess income tax liability of category $\mathrm{C}$ taxpayers. The expectations emanate from the very nature of standard assessment and its supposed solution for easing the problems that used to be manifested. Conceptually, income tax assessment refers to an impartial determination of the amount of tax for a given item that is subject to taxation. However the subsequent enactment of the regulation for then better regulatory purpose has come with a little room for reducing the inherent problems of the hard to tax categories or groups. The prevailing shortcomings of tax assessment of these groups include investment of extra administration cost, escaping of tax net, under-taxation, low tax compliance behavior, and/or uncertainty on the part of the tax authority and taxpayers attributable to the difficulty of locating the actual amount of tax liability to be paid. This study focus on business income tax in category ' $\mathrm{C}$ ' because business income tax categorized under ' $\mathrm{A}$ ' and ' $\mathrm{B}$ ' income taxes liabilities are determine based on their book of account (financial statement). On the other hand, Category ' $\mathrm{C}$ ' taxpayers their daily income is estimated by assessment committee and income tax liabilities is determine by tax collectors rather than declaring their income by themselves.

\section{Objective of the study}

The general objective of the study was to assess tax collection system and its challenges on category ' $\mathrm{C}$ ' tax payers of Nekemte town.

The specific objectives of this study were as follows:

- To assess tax assessment and collection practices in the selected town.

- To identify tax payers' problems related to tax assessment and collection.

- To identify the problems associated with tax collectors related to tax assessment and collection 


\section{Significance of the study}

The findings of this study may give clear understanding of what problems are there and how those problems are handled by both tax payers and administrators. Thus, the government will be able to adopt a comprehensive strategy, and minimize the observed problems to increase tax revenue and contributing to solve the problem of unfair tax estimation for tax payers. Furthermore the results of finding will serve as a reference for other researchers on this area.

\section{METHODOLOGY OF THE STUDY}

The researcher used qualitative research approach and cross sectional descriptive type of research design. The source populations for the study were all Category "C" Service giving tax payers in Nekemte town. It included the business sectors and concerned employees of the revenue authority office so as to identify the tax collection system and assessment in the selected area.

\section{Sample Size and Sampling Techniques}

According to Yamane, $\mathrm{n}=\mathrm{N} /\left[1+\left(\mathrm{Ne}^{2}\right)\right]$

Where $\mathrm{n}=$ is the sample size

$\mathrm{N}=$ is the population

$\mathrm{e}=$ is the error limit $(0.05$ on the basis of $95 \%$ confidence level $)$

However, in the context of this study, the total Category C Tax Payers in Nekemte town are 3271 as of September, 2018. Out of which only 548 were Category C Service Giving Tax Payers Business owners while the rest are sellers.

Therefore, the researchers will survey 164 Category C Service Giving Tax Payers in Nekemte town which is around $30 \%$ of the total population. The study used both primary \& secondary data. Secondary data was also collected through document analysis from published and unpublished sources. The survey data was gathered using structured questionnaire. A survey method helped in capturing attitudes or patterns of past behavior. In addition, the researcher interviewed concerned employees and government officials to get detail information. The researcher also used FGD as method of data collection to get full understanding of cross sectioning the answers/feedback with other methods of data collection. After the required information was collected from target respondents, the researcher employed different statistical tools to present, analyze, interpret and conclude the findings. Thus, in order to minimize the burdens of doing manually, SPSS and MS-Excel was used to analyze the data. Moreover, descriptive analysis such as, percentage, mean and frequency distribution was used to present/categorize the demographic characteristics of the respondents and analyzed the result of finding.

\section{RESULTS AND DISCUSSION}

A total of 15 employees and 80 tax payers were included in the final sample. Out of the 15 and 80 questionnaires distributed to tax office personnel and taxpayer respondents respectively, only 10 personnel and 70 taxpayers gave their response.

\section{ANALYSIS OF RESPONSES FROM TAX OFFICERS}

Tax payers were asked different questions regarding tax imposition, collections and problems they faced during collection. The result is indicted in the following table: 
Table 1. Response of tax office personnel if the right person is assigned at the right position

Question $\quad$ Response Number $\%$

\section{respondents}

Do you think that your office assigned the right persons to the right job position?

Yes
No
Total
Yes
No
Total
Yes
No
Total
Yes
No
Total
Yes
No
Total
Yes
No
Total
Yes
No

$6 \quad 60$

Is the number and qualification of the employees at your office sufficient to assess and collect category " $\mathrm{C}$ " tax efficiently?

Did you receive any training relevant to your duties and responsibilities?

Is there a clear policy and regulation for assessment and collection of category " $\mathrm{C}$ " tax?

Do category "C" tax payers pay the proper amount they should?

Do category "C" tax payer pay their tax on time?

Does your office provide regular information to category " $\mathrm{C}$ " taxpayers to create tax awareness?

$\begin{array}{lll}\text { No } & 4 & 40 \\ & & 40 \\ \text { Total } & \mathbf{1 0} & \mathbf{1 0 0} \\ \text { Frequently } & 6 & 60 \\ \text { Sometimes } & 3 & 30 \\ \text { Never } & 1 & 10 \\ \text { Total } & \mathbf{1 0} & \mathbf{1 0 0} \\ \text { Yes } & 8 & 80 \\ \text { No } & 2 & 20 \\ \text { Total } & \mathbf{1 0} & \mathbf{1 0 0} \\ \text { Yes } & 4 & 40 \\ \text { No } & 4 & 40 \\ \text { Indifferent } & 2 & 20 \\ \text { Total } & \mathbf{1 0} & \mathbf{1 0 0}\end{array}$

To what extent do taxpayers complain about the way the tax is assessed and collected?

Have you ever faced any problem during the collection of category
"C" tax?

Do you think that the tax assessment procedures for category " $\mathrm{C}$ " tax have any pitfalls

Total

10

40

100

40

60

100

80

20

100

100

0

100

60

40

100

60

40

100

60

40

60

30

80

40

100

Source: Survey, 2019

The following paragraphs present the responses of the tax office personnel. Table 6 demonstrates that majority $(60 \%)$ of the tax officers believe that in their office right person is assigned at the right position. The remaining but significant number (40\%) of the respondents, nevertheless, does not agree with the claim of assigning the right person at the right post.

Table 6 also shows that only $40 \%$ of the respondents believe that their office assigned sufficient number of adequately qualified personnel who are able to assess and collect tax efficiently. The majority (60\%) of tax officers, however, did not agree with this assertion. This inevitably affects the operations and effectiveness of the tax office. Further, Oldman (1967), the tax authorities can be perceived weak by taxpayers and this could might result in tax evasion.

Respondents who said that their office did not respect the principle of right person at the right position to assess and collect category " $\mathrm{C}$ " tax efficiently mentioned the following as reasons for the assignment of less appropriate personnel: - as a short term solution to address the shortage of manpower assignment by political affiliation loose recruitment procedures.

In addition, Table 6 also shows that $80 \%$ of the tax officers indicate that they get regular training relevant to their duties and responsibilities. The remaining $20 \%$ of the respondents indicated that they did not get any training. The respondents who gave an affirmative response were also asked to list the type of training they received. They indicated that they have received short term trainings on areas such as tax audit, Tax assessment, tax regulations and guidelines, estimating daily income, computer applications and data encoding and other trainings based on respective job position.

This undoubtedly enables the tax personnel to develop simple and user friendly tax administrative systems and procedures as well as to have sufficient powers to effectively enforce them.

Moreover, table 6 indicates that tax officer respondents unequivocally (100\%) replied that there is a clear 
policy and regulation for assessment and collection of category " $\mathrm{C}$ " tax.

Table 6 also shows that majority (60\%) of the tax officers believe that category " $C$ " tax payers are paying the proper amount of tax as they should. The remaining but significant proportion (40\%) of the respondents, however, are of the view that category " $C$ " tax payers are not paying the right amount they should. Those who said "No" reflected the existence of both overstatement or understatement of tax liability. The reasons for this are said to be lack of continuous market assessment and assessment of tax liabilities based only on daily sales.

Furthermore, table 6 depict that $60 \%$ of the respondents indicated that category "C" taxpayers pay their tax liability before or on the due date. However, $40 \%$ of the respondents stated that taxpayers do not keep up with the schedule. They replied that the possible reasons of tax payers for failing to meet deadlines, they listed several reasons; some of which are: economic difficulties owing to overstatement of tax tradition of rush hour payment

From Table 6 above, we can understand that $60 \%$ of the respondent in the tax office clearly stated that, the tax authority provides regular information to category " $C$ " taxpayers to create tax awareness. This helps to inculcate in taxpayers a sense of responsibility towards taxation and ultimately promotes a positive view to voluntary compliance.

Respondents were also provided with a list of options to indicate the methods they use to create awareness among category $\mathrm{C}$ taxpayers. Accordingly, the methods they selected were: mass media TV, Radio, Brochure, public meetings and Poster (banner).

In addition, tax officers were asked to indicate the level of complaint raised by the taxpayers about the way the tax is assessed and collected. Thus, Table 6 illustrates that $60 \%$ and $30 \%$ and of the respondents witnessed that tax payers complain frequently and sometimes, respectively. Only $10 \%$ of the tax officers indicated that taxpayers have never complained on the way the tax is assessed and collected. Those of the respondents who said 'Frequently' were asked to indicate the major complaints raised by the taxpayers. The complaints were: tax overstatement, tax inequity. Tax overstatement usually results in rates beyond the common businesses ability to pay, which makes it very hard for government as well to enforce payment and leads to the closure of enterprises, which otherwise could have continued to provide income and jobs to the national economy.

The above table 6 shows that $20 \%$ of the tax office personnel indicated that they did not face any problem during tax collection, majority $(80 \%)$ of the respondents reported that they do face problems. Among the problems reported as happened during tax collection were: taxpayers' lack of awareness on the procedures taxpayers' failure to present all relevant documents presentation of wrong information by the taxpayers' wastage of time by addressing taxpayers' complaint work overload due to rush hour appearance of taxpayer's shortage of man power.

When tax office personnel were asked if they think that the tax assessment procedures for category " $\mathrm{C}$ " tax have any pitfalls, $40 \%$ of the respondents indicated that the procedures does not have any pitfall. An equal proportion $(40 \%)$ of the respondents, however, believed that the procedure have some flaw. The remaining $20 \%$ of the respondents were indifferent on the issue.

Those of the respondents who believed that the tax assessment procedures for category " $\mathrm{C}$ " tax have some pitfalls were asked to mention some of the limitations. The major comments are: as the assessments are made based on subjective estimation they lack reliability, entails under or over statement, deplete trust, and nurture corruption, deficiency of the system to ensure vertical and horizontal equity among taxpayers.

Tax officers were also promoted with an open ended question to list the major problems they face in the collection and administration of category " $\mathrm{C}$ " tax. Accordingly, some of the problems stated by most of the respondents were: since most of the category " $C$ " taxpayers do not have books of account, it is challenging for the tax assessor to determine taxable income rightly lack of tax assessors faithfulness in determining taxable amount liability to corruption due to lack of standard procedure for category " $\mathrm{C}$ " tax assessment stock concealment by taxpayers lack of automation of the tax assessment and collection system difficulty of assessors to locate taxpayers' address. 
ANALYSIS RESPONSES FROM TAX PAYERS

Table 2. The view of taxpayers about taxation

\begin{tabular}{|c|c|c|c|}
\hline Question & Options & Number & \% of respondents \\
\hline \multirow[t]{5}{*}{ How do you view tax? } & As a privilege & 58 & 83.3 \\
\hline & As a debt & 0 & 0 \\
\hline & As an obligation & 4 & 5.6 \\
\hline & Indifferent & 8 & 11.1 \\
\hline & Total & 70 & 100 \\
\hline \multirow{3}{*}{$\begin{array}{l}\text { Do you receive any briefing on tax } \\
\text { assessment and collection from the tax } \\
\text { authority? }\end{array}$} & Yes & 54 & 77.8 \\
\hline & No & 16 & 22.2 \\
\hline & Total & 70 & 100 \\
\hline \multirow{3}{*}{$\begin{array}{l}\text { Do you have book of records for your } \\
\text { business transactions? }\end{array}$} & Yes & 39 & 55.6 \\
\hline & No & 31 & 44.4 \\
\hline & Total & 70 & 100 \\
\hline \multirow{4}{*}{$\begin{array}{l}\text { Do you believe the tax office is staffed } \\
\text { with adequate number of sufficiently } \\
\text { qualified personnel? }\end{array}$} & Yes & 27 & 38.8 \\
\hline & No & 39 & 55.6 \\
\hline & Indifferent & 4 & 5.6 \\
\hline & Total & 70 & 100 \\
\hline \multirow{4}{*}{$\begin{array}{l}\text { Are you clear with the concept and } \\
\text { procedures for the computation of } \\
\text { category " } C \text { " tax? }\end{array}$} & Clear & 12 & 16.7 \\
\hline & Somewhat clear & 35 & 50.0 \\
\hline & Not clear & 21 & 30 \\
\hline & Total & 70 & 100 \\
\hline \multirow{3}{*}{$\begin{array}{l}\text { What is your view on the fairness of the } \\
\text { tax assessment procedure? }\end{array}$} & Is it fair & 16 & 22.2 \\
\hline & It is not fair & 54 & 77.8 \\
\hline & Total & 70 & 100 \\
\hline \multirow{3}{*}{$\begin{array}{l}\text { Do you think that the tax assessment } \\
\text { procedure is appropriate? }\end{array}$} & Yes & 27 & 39.0 \\
\hline & No & 43 & 61.0 \\
\hline & Total & 70 & 100 \\
\hline \multirow{4}{*}{$\begin{array}{l}\text { How do you rate the cooperation and } \\
\text { treatment of tax office personnel } \\
\text { whenever you go to pay your tax } \\
\text { liability? }\end{array}$} & Very satisfactory & 4 & 5.6 \\
\hline & Satisfactory & 47 & 66.7 \\
\hline & Not satisfactory & 19 & 27.8 \\
\hline & Total & 70 & 100 \\
\hline \multirow{3}{*}{$\begin{array}{l}\text { Do you think the time given by the tax } \\
\text { authority to pay your tax liability } \\
\text { adequate? }\end{array}$} & Yes & 35 & 50.0 \\
\hline & No & 35 & 50.0 \\
\hline & Total & 70 & 100 \\
\hline \multirow{3}{*}{$\begin{array}{l}\text { Have you ever paid a fine due to your } \\
\text { failure to meet the deadlines set for the } \\
\text { payment of your tax liability? }\end{array}$} & Yes & 3 & 4.3 \\
\hline & No & 67 & 95.7 \\
\hline & Total & 70 & 100 \\
\hline
\end{tabular}

Source: Survey, 2019

Table 7 indicates that majority $(83.3 \%)$ of the tax payers view tax as a privilege, i.e. in the anticipation of better public services. Only $5.6 \%$ of the tax payers felt that tax is a debt and the rest $11.1 \%$ of the respondents view tax as an obligation. This indicates that taxpayers have a positive understanding as to why they pay taxes. This indicates that if successive works are done probably better results can be registered.

In addition, table 7 also presents the response of the tax payers when they were asked if the tax authority gives them any briefing on tax assessment and collection. While the majority $(77.8 \%)$ of them indicated that they do receive briefing, $22.2 \%$ of them answered the opposite. Since poor tax education practice and lack of consultation sessions between the tax authority and taxpayers result in poor tax collection, the office should strengthen the provision of sufficient education to taxpayers to boost awareness.

Though it is not obligatory for category " $C$ " taxpayers, maintaining books of accounts and supporting documents in accordance with proper accounting principles and in a manner acceptable to the Tax Authority is a commendable practice.

Table 7 also depicts the response of category "C" tax payers on having book of records. While $55.6 \%$ of them indicated that they have book of records, the remaining $44.4 \%$ said they do not have book of records for their financial transactions. This means that a quite a significant proportion of the category " $C$ " tax payers don't have any formal means to control their revenues and expense. Tax payers who do not maintain books of account were asked how they can manage their profit and loss in the absence of any record; their responses were simply by selling items at a price higher than they were purchased based on mere estimation by comparing their daily revenue and expense.

The fact that many business owners do not keep their books properly invites to general estimations, 
which are often arbitrary. So training is necessary on the one hand and on the other hand, national standards for bookkeeping, which would be respected in all taxation offices nationwide need to be defined and introduced (ECC and EBDSN, 2005).

Moreover, table 7 indicates that majority $(55.6 \%)$ of the tax payers do not believe the tax office is staffed with adequate number of sufficiently qualified personnel. In contrast $38.8 \%$ of the tax payers indicated that they do believe the tax office is staffed with adequate number of sufficiently qualified personnel.

From the above table 7, taxpayers were asked if the concept and procedures for the computation of category "C" tax is clear to them, only $16.7 \%$ of the tax payers said that it is clear for them. While half $(50 \%)$ of the tax payers indicated it is somewhat clear, the rest $33.3 \%$ indicated the concept is not at all clear for them. A good tax system is one which is designed on the basis of an appropriate set of principles, such as equality or fairness and certainty. Taxes must be fair and equitable, i.e., citizens should be taxed in proportion to their abilities to pay and in proportion to the benefit they derive from the government. According to James and Nobes (2000), the most obvious requirement of equity or fairness is to treat equal people in equal circumstances in an equal way.

Furthermore, tax payers were asked whether the tax they are paying is based on their ability-to pay or not. Table 7 above demonstrates that only about a fifth (22.2\%) of the taxpayers believe that the tax assessment is fair. However, the majority $(77.8 \%)$ of category "C" tax payers are of the view that the tax assessment is not fair and equitable. For voluntary system to work successfully, tax payers must be assured that taxes are levied fairly and that everyone pays his share. If the feeling that the tax system has collection loopholes and evasions becomes widespread, if taxpayers learn their neighbors earning comparable income pay substantially less or enjoy taxfree living, their morale to pay tax declines. Once such attitude prevailed among the public it will be difficult to rectify it and demands authorities huge compliance and collection costs.

The respondents were also if they think the tax assessment policy is appropriate, the majority (61\%) of the tax payers indicated that it is not appropriate. On the other hand, a significant proportion (39.0\%) of the tax payers said that it is appropriate (Table 7). This can be due to the fact that the tax systems are usually not elaborated after proper consultation with the business community and due to the frustration on tax overstatement as an outcome of subjective estimation.

Table 7 above also shows that, with regard to the cooperation and treatment of tax office personnel, while only $5.6 \%$ of the tax payers feel that it is very satisfactory, the majority $(66.7 \%)$ of them believe it is only satisfactory. The remaining $27.8 \%$ of the taxpayers however consider that the service is not satisfactory. Those who felt the service is unsatisfactory pointed out that:

$>$ some tax office personnel consider taxpayers as a subject than a partner tax assessors do not declare the taxable amount in proper time

$>$ more time consuming and bureaucratic process

Taxpayers be regarded as partners who contribute their share to the national revenue. Taxpayers who are aware of their rights and expect, and in fact receive, a fair and efficient treatment are more willing to comply. Any irritations as above and such as poorly drafted forms, long waiting lines, bureaucratic hassles, rudeness from officials, cumbersome appeal procedures can repel even the most loyal taxpayers.

Moreover, table 7 indicates that $50 \%$ of the tax payers do think that the time given by the tax authority to pay their tax liability is adequate, an equal proportion (50\%) of them do not.

Article N0 88 of the Proclamation No. 286/220 stipulates that a taxpayer who fails to pay tax liability on the due date is subject to: A penalty of $5 \%$ of the amount of unpaid tax on the first day after the due date has passed and An additional $2 \%$ of the amount of tax that remains unpaid on the first day of each month thereafter.

In addition, only $4.3 \%$ of the taxpayers indicated that they did pay a fine due to their failure in meeting deadlines to pay their tax liability. The majority (95.7) of them, however, witnessed that they didn't pay any fine so far as they disburse their tax obligation timely.

The respondents were given opportunities through some open ended questions to give general comment on the overall tax system. Accordingly, they issued several comments regarding problems. These are categorized and listed below:

$>$ the tax system lacks fairness or equity

$>$ absence of transparency in the overall tax system

$>$ high prevalence of illegal trade (many business operators are not accommodated by the tax system)

$>$ lack of awareness, and poor communication between the tax authority and taxpayers lack of adequate provision of social services weakness in enforcing the tax regulations lack of sufficient qualified personnel subjectivity of the tax assessment that frequently results in over-taxation

The respondents were also asked to indicate some possible measures that have to be taken in order to bring about useful change in the tax system and ultimately improve voluntary tax compliance. Their comments are briefly presented below.

$>$ Improving relationship of the tax authority with the public educating the taxpayers and conducting consultation sessions 
$>$ Providing necessary information to taxpayers regarding the provision of services and utilization of tax revenues

$>$ Reducing tax rates and making the collection procedures simple and transparent strengthening legal enforcement and penalties

\section{CONCLUSION}

In general, since tax is the main source of public expenditure, the assessment and collection of tax at any category should be effective to generate adequate amount of funds that can cover all the capital that the government needs. The study indicated that lack of awareness creation programs for taxpayers, failure of most of the taxpayers to maintain books of account to control their operations, lack of adequately qualified personnel, lack of objective tax estimation procedures and the resultant tax under- and over-statement, lack of taxpayers awareness about tax procedures and calculations are some of the major problems on category " $\mathrm{C}$ " tax assessment and collection of we believe this problems will be simplified if not eliminated.

\section{REFERENCES}

Bekelech, H. (2005). The evaluation of tax administration in category "C" tax payers a case of study in Wolaita soddo (Soddo city) Administration revenue author branch Office.

C.R. Kothari. (2004), Research methodology, second revised edition.

Ethiopian Chamber of Commerce (ECC) and Ethiopian Business Development Services Network (EBDSN). (2005). Taxation in Ethiopia Direct and Indirect Taxes-Categories of Tax Payers Declaration of Income and Assessment of Taxes Tax Incentives. Ababa 1/2005.

Fjeldstad,O. and Ranker, L. (2003). Taxation and Tax Reforms in Developing Countries: Illustration from subSaharan Africa. Bergen, Norway: Chr.Michelsen Institute.

Income Tax (Amendment) Proclamation No. 608/2008 or 608/2001 EC).

Income Tax Proclamation No. 286/2002 or 286/1994 EC.

James, S. and Nobes, C. (2000). The Economics of Taxation: Principles, Policy and Practice 7th edition. PrenticeHall.

Joseph R.A. Ayee, (2008). Building tax compliance through reciprocity with government. Faculty of Social Studies, University of Ghana

Konstantin P. (2016). Presumptive Taxation and Gray Economy: Lessons for Bulgaria, 4 (Dec. 2015) (WP 0512/1, Center for the study of Democracy

Lee, B. and Richard, K. (1998). Taxation of income from business and investment, in tax law design and drafting 2, 1-36 (Victor Thuronyied).

Lemessa T. (2007). A Research Project on Determinants of Taxpayers' Voluntary Compliance with Taxation: The Case Study of Dire Dawa City. Addis Ababa.

Mesele, K. and Tesfahun, T. (2016). Problems Associated with Tax Payers and Revenue Authority in Case of Dessie Town, Northern Ethiopia.

Misrak T. (2008). Ethiopian Tax Accounting: Theory and Practice, $1^{\text {st }}$ ed. Addis Ababa.

Mohani, A. (2001). Personal income tax non-compliance in Malaysia. PhD thesis. Victoria University: Melbourne, Australia.

Mohani, A., and Sheehan, P. (2004). Estimating the extent of income tax non-compliance in Malaysia and Australia using the gap approach (part II). Tax National

Muuz A.( 2015). Evaluation of the efficiency of standard assessment for Category "C" taxpayers in Ethiopia: the case of Tigray regional State VOL. 4:1page 108-127

Negarit Gazette, (2002). Income tax Proclamation No. 286/2002, FDRE: Addis Ababa, BSPE.

Negarit Gazette, (2002). Income Tax Regulation 78/2002, FDRE: Addis Ababa, BSPE.

Selamawit, W. Genet,Y . and Tigist, T. (2012). Category "C" Tax Assessment and Collection.

Taddele, G. (2010). Tax reforms and their implications on revenue productivity of Ethiopian tax system: Unpublished thesis. Mekelle: Mekelle University.

The Income Tax Proclamation, Proclamation No. 286/2002, FED. NEGARIT GAZETTA, 8th year No. 34 4th July 2002.

Tilahun A. (2014), Determinants of Tax Compliance Behavior in Ethiopia: The Case of Bahir dar City Taxpayers, Journal of Economics and Sustainable Development, Vol.5, No.15 2014.

Vadde \& Gundarapu, (2012), 'Factors that influence rental tax payers' compliance with tax system' an empirical study of Mekelle city, Ethiopia, Journal of Arts, Science \& Commerce, Vol.- III, Issue-4(2).

Victor T. (1996), Presumptive Taxation in tax law design and drafting, Vol.1

Yohannes, M. and Zerihun, A. (2013). Assessing the Gaps and Problems that Exist between the Business Community and Tax Authorities of Dire Dawa Administration, ISSN 2224-607X, Vol.3.

Zerihun .A, (2013). Presumptive Income Taxation of Small Business in Ethiopia 